\title{
Seasonal Variations of Mercury Levels in Selected Medicinal Plants Originating from Poland
}

\author{
M. Ordak ${ }^{1,2,3}$ - M. Wesolowski ${ }^{1}$ - I. Radecka $^{1}$ - E. Muszynska ${ }^{4}$. \\ M. Bujalska-Zazdrozny ${ }^{2}$
}

Received: 16 October 2015 / Accepted: 9 February 2016 / Published online: 29 February 2016

(C) The Author(s) 2016. This article is published with open access at Springerlink.com

\begin{abstract}
The presence of mercury in the living cells may be caused by environmental pollution with this element, which is referred to as a toxic xenobiotic. Many literature reports have provided evidence for toxic effects of low levels of mercury in the human body. Therefore, it seems essential to investigate mercury content in food and in natural environment, particularly its seasonal variations. The objective of this study was to determine trace amounts of mercury in 45 samples of 20 medicinal plant species collected in northern Poland, in various seasons of the year, i.e., in autumn 2012 and then spring 2013. The results obtained showed that the levels of mercury in the herbs were lower in spring (3.66-34.89 ng/g) than in autumn $(4.55-81.54 \mathrm{ng} / \mathrm{g})$. The statistically significant correlation $(p<0.05)$ between the levels of mercury in herbs collected in spring and autumn indicates hazardous accumulation of the element in plants in autumn. The highest levels of mercury were found in leaves and plants growing in the vicinity of busy streets. Perennials plants have a significantly higher mercury levels as compared to those of monocarpic plants. Furthermore, commonly used herbal plants have a significantly higher mercury levels as compared to those less common.
\end{abstract}

M. Ordak

mordak@wum.edu.pl

1 Department of Analytical Chemistry, Medical University of Gdansk, Gdansk, Poland

2 Department of Pharmacodynamics, Centre for Preclinical Research and Technology (CePT), Medical University of Warsaw,

Warsaw, Poland

3 Chair and Department of Psychiatry, Medical University of Warsaw, Warsaw, Poland

4 Department of General Biology, Medical University of Bialystok, Bialystok, Poland
Keywords Mercury $\cdot$ Medicinal herbs $\cdot$ Seasonal variations of mercury levels

\section{Introduction}

Research into the chemical composition and pharmacological action of raw medicinal plant materials has confirmed the advantageous use of herbs in the prevention and treatment of numerous ailments. Apart from active substances, i.e., macroand microelements that are indispensable for health, medicinal plants may introduce toxic elements to the human body and impair its normal function. Although raw plant materials undergo quality control, their contamination with heavy metals has been reported $[1,2]$. Therefore, it seems justified to monitor the elemental composition of raw medicinal plant materials used in phytotherapy [3].

Mercury is one of the elements which in the living cells are considered to be dangerous xenobiotics. Usually, plants absorb mercury from soil through the root system and to a lesser extent through leaves, directly from the air [4-9]. In soil, mercury occurs in various chemical forms and is entrapped mainly in macromolecular humus substances. This element is available for plants in the amounts proportional to those released from soil, only in the methylmercury form. Mercury is easily transported through roots to the aerial parts of plants, where it is deposited in necrotic tissues, such as periderm and wood $[10,11]$. It has been shown that some plants are capable to translocate microelements from leaves to twigs and branches, just before the leaf fall period. Sparing the indispensable elements, plants also accumulate toxic mercury. The level of mercury in the plant should not be higher than $20 \mathrm{ng} / \mathrm{g}$ [10, 12].

According to some authors, mercury obtained from the socalled dry deposition can be rinsed out from the surface of 
living plants, e.g., by atmospheric precipitation [13, 14]. However, throughout the vegetation period, the level of mercury in plant tissues increases both due to dry and wet deposition, more intensely than in the surrounding soil. This is also caused by mercury mobility in the air-soil-plant system and its accumulation by certain plant species. It has been demonstrated that appropriate agrotechnical procedures can largely decrease mercury absorption by plants $[5,6,15,16]$.

Up to now, research into seasonal variations in mercury concentration and deposition has shown a marked relationship of its environmental content with its levels in the atmospheric air and surrounding soil. Studies conducted in an area of Atlantic Forest at Ilha Grande Island located in the south-east of Brazil showed substantial fluctuations of mercury in the vegetation season, depending on its content in the duff formed by tree leaves exposed to high mercury pollution. Industrial works situated close to the Island are responsible for the emission of mercury to the atmosphere. The mercury content in the leaves of trees that dominate in that region is the highest between June and August $(225 \pm 17 \mathrm{ng} / \mathrm{g})$, and the lowest between December and May $(94 \pm 54 \mathrm{ng} / \mathrm{g}$ ), depending on deposition of this element originating from duff (fallen leaves) and precipitation intensity. Similar results have been reported in studies on the magnitude of mercury deposition in the atmosphere over China and on the content of other elements in tree leaves in the south of Sweden. The soils are $\mathrm{Hg}$ contaminated in two ways: atmospheric deposition and leaching through the soil profiles of $\mathrm{Hg}$-organic matter complexes [10, 15, 17, 18]. Atmospheric Hg may account for all of the $\mathrm{Hg}$ deposited in litterfall [12]. It has been found that mercury accumulation in plants increases with time. Chronic deposition leads to mercury arrest mainly in roots $[5,19]$. Skinner et al. showed that four species of aquatic plants exposed to mercury for 30 days accumulated and bound the mercury within the roots [20]. The content of mercury in plants is the highest during the day, being twofold lower at night [21]. Other authors have found a significant correlation between vegetation period and the concentration of mercury in the leaves of several medicinal plants. The concentration of mercury in the tested leaves increased in the period of enhanced photosynthesis [22].

Mercury accumulation in medicinal plants is a particularly unfavorable phenomenon [23, 24]. Since not many literature data are available on the content of mercury in medicinal plants, the objective of the current study was to determine and assess its seasonal variations in medicinal herbs. There are no reports in the literature which examined whether there is significant influence of vegetation and utility on concentration of mercury in medicinal plants which were collected at different seasons of the year.

\section{Materials and Methods}

\section{Plant Material}

A set of 45 samples obtained from 20 medicinal plant species was analyzed. The plants had been collected in northern Poland in autumn 2012 and spring 2013. Taxonomic classification of the plants was verified based on a dictionary of environmental science. Samples were collected in the area of Tri-city (Gdansk, Sopot, Gdynia), mainly in forests, as well as in allotment and kitchen gardens. The plants were collected at the same sites in autumn and spring. The content of mercury in the soil depends on interplay of many factors. The most important role is played by air temperature, amount of rainfall, and such soil characteristics as its $\mathrm{pH}$, aeration, content of organic compounds, and certain elements, e.g., nitrogen, iron, calcium, and phosphorus in the soil. Medicinal plants species used in the study were derived from areas characterized by different soil conditions. These were allotments and kitchen gardens located at different distance from the street and forest as well. Detailed data on the samples and collection sites are presented in Table 1.

The harvested medicinal plants were dried at room temperature, in an airy place to reduce a high water content that could have initiated adverse biological processes. After drying, foreign material such as other plant parts, weeds, waste, soil particles, and dust were manually separated. The dried up plants were placed in paper bags that were stored till analysis in a dry, dark place, with no exposure to sun rays.

\section{Determination of Mercury}

A Varian SpectrAA 250 Plus absorption/emission spectrometer (Varian, Australia) was used to quantify mercury concentration using cold vapor technique (Cold Vapor Atomic Absorption Spectrometry, CVAAS). In this technique, mercury contained in a sample is reduced to its elemental form. Next, using argon stream, mercury is washed out from the solution in the form of vapors and moved to an absorption cuvette, where it absorbs the radiation emitted by a cathode mercury lamp [24-26]. The calibration graph was determined based on the analysis of standard solutions, containing: 10,20, 50,75 , and $90 \mathrm{ng} \mathrm{Hg}$ in $1 \mathrm{~mL}$ of solution. The graph was linear and described by equation $A=0.011 \times \mathrm{c}$ and $R^{2}=0.9959$.

A wet-digestion of the samples was carried out according to a procedure developed previously [27], with slight modifications. The weighed amount $(1 \pm 0.05 \mathrm{~g})$ of the plant material was transferred to a Teflon vessel. Next, $5 \mathrm{~mL}$ of redistilled water obtained from a quartz apparatus Heraeus Quarzglas (Destamat ${ }^{\circledR}$, Germany) and $5 \mathrm{~mL}$ of concentrated $(65 \%)$ $\mathrm{HNO}_{3}\left(\right.$ Selectipur ${ }^{\circledR}$, Darmstadt, Merck) were added. The vessel was tightly closed, put aside for $3 \mathrm{~min}$, and then vortexed. Wet digestion was performed in a high-pressure microwave 
Table 1 Analyzed plant material

\begin{tabular}{|c|c|c|c|c|}
\hline $\begin{array}{l}\text { Sample } \\
\text { number }\end{array}$ & Plant species & Collected morphological part & Place of harvest & Therapeutic effect \\
\hline $\begin{array}{l}1 \\
2\end{array}$ & $\begin{array}{l}\text { Petroselinum sativum } \\
{\text { (Parsley })^{\mathrm{a}} \mathrm{c}}^{\text {c }}\end{array}$ & Leaves & Allotments, $30 \mathrm{~m}$ from the street & $\begin{array}{l}\text { Diureticum, carminativum, stomachicum, } \\
\text { spasmolyticum }\end{array}$ \\
\hline $\begin{array}{l}3 \\
4\end{array}$ & $\begin{array}{l}\text { Hedera helix } L \text {. } \\
(I v y)^{\mathrm{b}, \mathrm{d}}\end{array}$ & Leaves & Home garden, $20 \mathrm{~m}$ from the street & $\begin{array}{l}\text { Expectorans, sedativum, rubefaciens, } \\
\text { antirheumaticum, antipyreticum }\end{array}$ \\
\hline $\begin{array}{l}5 \\
6\end{array}$ & $\begin{array}{l}\text { Urtica dioica } L \text {. } \\
(\text { Nettle })^{\mathrm{a}, \mathrm{c}}\end{array}$ & The whole plant & Forest & $\begin{array}{l}\text { Diureticum, antirheumaticum, } \\
\text { haemostaticum, alterans, rubefaciens }\end{array}$ \\
\hline $\begin{array}{l}7 \\
8\end{array}$ & 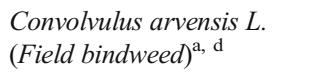 & $\begin{array}{l}\text { Roots } \\
\text { Leaves }\end{array}$ & Forest & $\begin{array}{l}\text { Purgans, depurativum, antisepticum, } \\
\text { hypotonicum, spasmolyticum }\end{array}$ \\
\hline $\begin{array}{l}9 \\
10\end{array}$ & $\begin{array}{l}\text { Sambucus nigra } L \text {. } \\
(\text { Elderberry })^{\mathrm{b}, \mathrm{c}}\end{array}$ & $\begin{array}{l}\text { Fruits } \\
\text { Leaves and flower buds }\end{array}$ & Forest & Expectorans, diaphoretic, diureticum \\
\hline $\begin{array}{l}11 \\
12\end{array}$ & $\begin{array}{l}\text { Anethum graveolens } L . \\
(\text { Dill })^{\text {a, c }}\end{array}$ & Leaves and flowers & Allotments, $30 \mathrm{~m}$ from the street & Stomachicum, carminativum \\
\hline $\begin{array}{l}13 \\
14\end{array}$ & 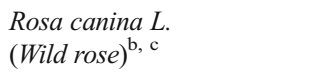 & $\begin{array}{l}\text { Leaves } \\
\text { Fruits }\end{array}$ & Home garden, $20 \mathrm{~m}$ from the street & $\begin{array}{l}\text { Alterans, cholagogum, diureticum, } \\
\text { adstringens, tonicum }\end{array}$ \\
\hline 15 & & Leaves & & \\
\hline 16 & & Flowers & & \\
\hline $\begin{array}{l}17 \\
18\end{array}$ & 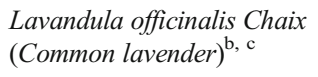 & Flowering tops of shoots & Home garden, $20 \mathrm{~m}$ from the street & Diureticum, cholagogum carminativum \\
\hline $\begin{array}{l}19 \\
20\end{array}$ & $\begin{array}{l}\text { Bellis perennis } \\
(\text { Daisy })^{\mathrm{b}, \mathrm{d}}\end{array}$ & The whole plant & Allotments, $30 \mathrm{~m}$ from the street & Depurativum, alterans, diureticum \\
\hline $\begin{array}{l}21 \\
22\end{array}$ & $\begin{array}{l}\text { Solidago gigantea Aiton } \\
(\text { Giant goldenrod })^{\mathrm{b}, \mathrm{d}}\end{array}$ & Flowering tops of shoots & Forest & Epurativum, antirheumaticum, hypotonicum \\
\hline $\begin{array}{l}23 \\
24\end{array}$ & $\begin{array}{l}\text { Taxus baccata } L . \\
(\text { Yew })^{\mathrm{b}, \mathrm{d}}\end{array}$ & $\begin{array}{l}\text { Leaves } \\
\text { Leaves }\end{array}$ & Park & Antihelminticum \\
\hline 25 & & Fruits & & \\
\hline $\begin{array}{l}26 \\
27\end{array}$ & $\begin{array}{l}\text { Altheae rosea L. Cav. } \\
(\text { Alcea rosea })^{\mathrm{a}, \mathrm{d}}\end{array}$ & Flowers & Home garden, $30 \mathrm{~m}$ from the street & Emolliens, protectivum \\
\hline $\begin{array}{l}28 \\
29\end{array}$ & $\begin{array}{l}\text { Rubus idaeus L. } \\
\text { (Raspberry) }^{\mathrm{b}, \mathrm{c}}\end{array}$ & $\begin{array}{l}\text { Leaves } \\
\text { Fruits }\end{array}$ & Allotments, $30 \mathrm{~m}$ from the street & Diureticum, adstringens \\
\hline 30 & & Leaves & & \\
\hline $\begin{array}{l}31 \\
32\end{array}$ & $\begin{array}{l}\text { Rubus fruticosus L. } \\
\text { (Blackberry })^{\mathrm{b}, \mathrm{c}}\end{array}$ & $\begin{array}{l}\text { Leaves } \\
\text { Fruits }\end{array}$ & Allotments, $30 \mathrm{~m}$ from the street & Diureticum, expectorans \\
\hline 33 & & Leaves & & \\
\hline $\begin{array}{l}34 \\
35\end{array}$ & 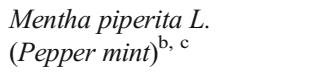 & Leaves & Allotments, $30 \mathrm{~m}$ from the street & Cholagogum, digestivum, antisepticum \\
\hline $\begin{array}{l}36 \\
37\end{array}$ & $\begin{array}{l}\text { Salvia officinalis } L . \\
(\text { Sage })^{\mathrm{b}, \mathrm{c}}\end{array}$ & Leaves & Home garden, $10 \mathrm{~m}$ from the street & Antidiabeticum, alterans, antiphlogisticum \\
\hline $\begin{array}{l}38 \\
39\end{array}$ & $\begin{array}{l}\text { Capsella bursa-pastoris } \\
\text { (Shepherd's purse) }^{\mathrm{a}, \mathrm{d}}\end{array}$ & The whole plant & Home garden, $20 \mathrm{~m}$ from the street & Haemostaticum, spasmolyticum, antipyreticum \\
\hline $\begin{array}{l}40 \\
41\end{array}$ & $\begin{array}{l}\text { Lamium album L. } \\
\text { (White dead-nettle })^{\mathrm{b}, \mathrm{d}}\end{array}$ & Flowering tops of shoots & Forest & Expectorans, haemostaticum, emolliens \\
\hline $\begin{array}{l}42 \\
43\end{array}$ & $\begin{array}{l}\text { Monarda didyma } \\
(\text { Bee balm })^{\mathrm{a}, \mathrm{d}}\end{array}$ & Leaves & Home garden, $10 \mathrm{~m}$ from the street & Antisepticum, stomachicum \\
\hline $\begin{array}{l}44 \\
45\end{array}$ & 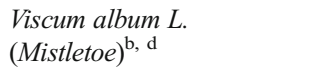 & Leaves and young branches & Home garden, $10 \mathrm{~m}$ from the street & $\begin{array}{l}\text { Hypotonicum, vasotonicum, diureticum, } \\
\text { haemostaticum }\end{array}$ \\
\hline
\end{tabular}

${ }^{\text {a }}$ Polycarpic plant

${ }^{\mathrm{b}}$ Monocarpic plant

${ }^{\mathrm{c}}$ Commonly used plant

${ }^{\mathrm{d}}$ Less common plant

mineralizer UniClever MB-1z (Plazmatronika, Wrocław, Poland) in three steps, using the parameters shown in Table 2. The cooling time of a sample after wet digestion, before opening of the cap, was $10 \mathrm{~min}$. The solution was placed in a volumetric flask and diluted with redistilled water up to $25 \mathrm{~mL}$. 
Table 2 Terms of mineralization of analyzed samples

\begin{tabular}{llllll}
\hline $\begin{array}{l}\text { Mineralization } \\
\text { step }\end{array}$ & Time (min) & $\begin{array}{l}\text { Power microwave } \\
\text { generator (\%) }\end{array}$ & $\begin{array}{l}\text { Minimum } \\
\text { pressure (atm.) }\end{array}$ & $\begin{array}{l}\text { Maximum } \\
\text { pressure (atm.) }\end{array}$ & $\begin{array}{l}\text { Temperature }\left({ }^{\circ} \mathrm{C}\right) \\
{[\text { min-max }]}\end{array}$ \\
\hline I & 6 & 50 & 17 & 20 & $150-180$ \\
II & 5 & 85 & 32 & 35 & $150-180$ \\
III & 5 & 100 & 38 & 40 & $180-200$ \\
\hline
\end{tabular}

The accuracy of the method was assessed using a certified reference material, white cabbage leaves $\mathrm{BCR}^{\circledR}-679$ (IRMM, Geel, Belgium), with a declared mercury content of $6.3 \mu \mathrm{g} / \mathrm{kg}$. The analyte recovery was $100.32 \pm 0.95 \%$. To check the precision of mercury measurements, absorption of two randomly chosen solutions was determined, for which 12 repetitions were performed. The relative standard deviations, RSD, were 0.74 and $1.7 \%$, respectively. Thus, it was stated that the measurements were accurate and precise.

\section{Statistical Analysis}

Each sample was analyzed in triplicate and the results were presented as the arithmetic mean (M) with standard deviation (SD). All concentrations of mercury in the plant samples were expressed in ng/g of dry mass (d.m.). The statistical analysis was performed using the IBM SPSS Statistics 22 software, at a $p<0.05$ significance level. The Student's $t$ test for independent samples was applied to check for statistically significant differences in the mercury content in the plant materials, depending on the season of the year. The Student's $t$ test for single sample was employed to compare the results with the norms established by the Ministry of Health [28]. Correlations between the levels of mercury in the particular parts of plants were determined by correlation analysis.

\section{Results}

\section{Mercury in Medicinal Plants}

The analysis of mercury content in medicinal plants showed its range to be $3.66-81.54 \mathrm{ng} / \mathrm{g}$. The highest content of mercury $(81.54 \mathrm{ng} / \mathrm{g})$ was found in autumn in the leaves of yew (sample 23), whereas the lowest in spring in white dead-nettle blossoming tops $(3.66 \mathrm{ng} / \mathrm{g}$, sample 41). High concentration of mercury was observed in daisy (sample 19, $68.54 \mathrm{ng} / \mathrm{g}$ ). The content of mercury in nettle (sample 6) did not exceed $5 \mathrm{ng} / \mathrm{g}$. A similar low content of mercury was found in leaves and blossom of Anethum graveolens (sample 12).

Statistically significant differences were found in the content of mercury between the plant materials collected in spring and autumn $(t(31.11)=2.66 ; p<0.05)$. Figure 1 presents the mean content of mercury in medicinal plant with dispersion of the results. The mean level of mercury in the medicinal herbs and dispersion of the results were higher in autumn $(M=22.33 ; \mathrm{SD}=4.13)$ than in spring $(M=10.36$; $\mathrm{SD}=1.78)$. The difference was either slight, as in the case of blossoming sprout tops of giant goldenrod (samples 21, 22), or large, e.g., in the leaves of yew (samples 23, 25). In autumn months, more extreme results or deviations were obtained.

The comparison of mercury levels in various morphological parts of the plants showed that the content of this element exhibited the greatest fluctuations in leaves and herbs. A slight dispersion of the results around the mean was observed in fruits and inflorescences. Furthermore, the leaves of ivy (samples 3, 4), bee balm (samples 42, 43), yew (samples 23, 25), raspberry (samples 28,30 ), blackberry (samples 31,33 ), wild rose (samples 13, 15), and sage (samples 36,37 ) were found to be the highest contaminated with mercury. The content of this toxic element in leaves ranged from $5.84 \mathrm{ng} / \mathrm{g}$ (sample 33) to $81.54 \mathrm{ng} / \mathrm{g}$ (sample 23). High content of mercury was also found in daisy whose all parts are used as a medicinal herb and in yew fruits (sample 24;27.63 ng/g). High levels of this element were also detected in the flowers of Alcea rosea$27.90 \mathrm{ng} / \mathrm{g}$ (sample 26), whereas in the roots of field bindweed (sample 7), the content of mercury was low $(6.67 \mathrm{ng} / \mathrm{g})$.

The Student's $t$ test showed statistically significant differences in the levels of mercury only in leaves (Fig. 2) collected in spring and autumn $(t(9.52)=2.67 ; p<0.05)$. In the leaves collected in autumn, the mercury level was significantly higher $(M=32.35$; $\mathrm{SD}=7.59)$ as compared to that in the spring months $(M=11.17$; $\mathrm{SD}=2.35)$.

The levels of mercury in the herbs studied were compared to the norms established by the Ministry of Health [28]. According to the regulation, mercury content should not exceed $10 \mathrm{ng} / \mathrm{g}$ in food products for children and $30 \mathrm{ng} / \mathrm{g}$ in dried medicinal and culinary herbs. The level of mercury in plants collected in spring appeared to be significantly lower than the accepted norm $(t(17)=4.38 ; p<0.001)$. However, the elevated content of mercury in autumn was not high enough to achieve a statistically significant difference $(t(17)=1.29$; $p>0.05)$.

\section{Collection Site of Plants}

The results of this study showed a massive effect of the collection site (home gardens, allotments, forest) on the mercury content. Medicinal herbs collected in the autumn in allotments 
Fig. 1 Average concentration of mercury in the analyzed

medicinal herbs $(M \pm \mathrm{SD})$
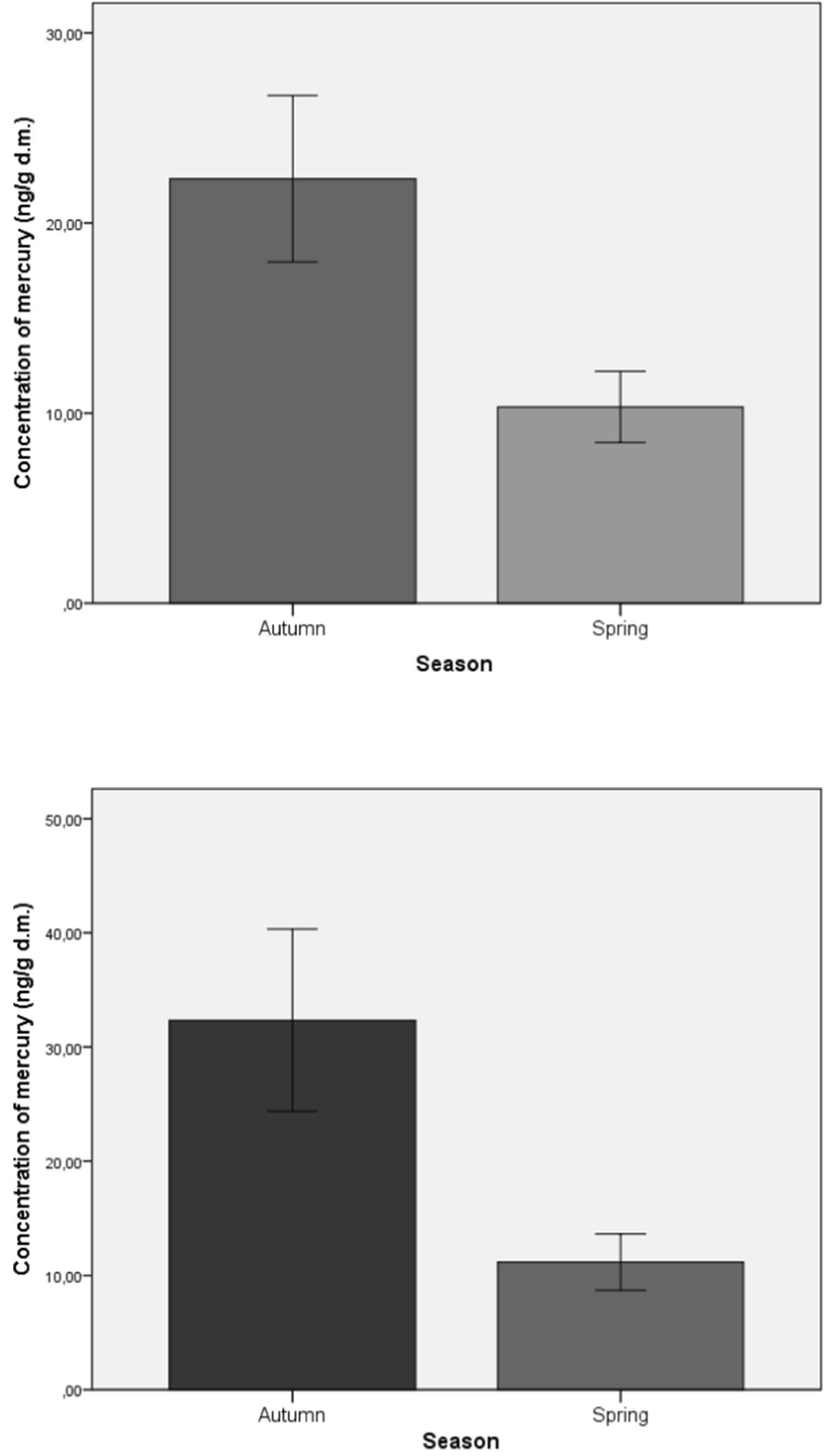
and home gardens exhibited a significantly higher level of mercury $(M=24.63, \mathrm{SD}=4.54)$ compared to the plants collected in this season of the year in the forest $(M=11.37$; $\mathrm{SD}=3.78),(\mathrm{t}(7.3)=2.48 ; p<0.05)$. The highest levels of mercury were found in herbs collected in home gardens and allotments located in the close vicinity of places exposed to substantial pollution (busy streets, construction sites). These herbs included daisy (samples 19, 20), leaves of ivy (samples 3,4 ), and leaves of yew (samples 23, 25). However, the level of mercury was lower in samples harvested in natural environment, i.e., in forests or allotment gardens, where air pollution is probably the lowest. This can be easily exemplified by roots and leaves of field bindweed (samples 7,8 ) and the leaves of parsley (samples 1,2).

\section{Correlation Analysis}

The correlation analysis was employed to determine the relations between the levels of mercury in the medicinal herbs studied. The analysis revealed a significant positive and strong correlation between the levels of mercury in herbs collected in spring and autumn $(r=0.66 ; p<0.05$; Fig. 3$)$.

Herbal plants were also divided into another subgroups, namely polycarpic (perennials) and monocarpic (biennials or annuals). Perennials plants have a significantly higher concentration of mercury $(M=22.99$; SD $=7.35)$ in comparison to biennials and annuals $(M=5.22$; $\mathrm{SD}=0.71)$, $(t(7.13)=2.41 ; p<0.05)$. A significant and strong correlation between concentration of mercury in autumn and spring in both subgroups was found for polycarpic $(r=0.82 ; p<0.05$; Fig. 4) and monocarpic $(r=0.84$; $p<0.01$; Fig. 5) plants.

Herbal plants were also divided into the more or less common ones. Those which are more common have anti-inflammatory and diuretic activities among others. More commonly used herbal plants have a significantly decreased concentration of mercury $(M=10.23$; $\mathrm{SD}=1.23)$ in comparison to those less common $(M=19.95 ; \mathrm{SD}=4.6),(t(22.84)=2.04 ; p<0.05)$. A significant and strong correlation between concentration of mercury in autumn and spring in both subgroups was found for more common $(r=0.77 ; p<0.05$; Fig. 6) and less common $(r=0.92 ; p<0.01$; Fig. 7) plants.

Moreover, an attempt has been made to learn whether there is a significant relationship between the temperature at which the plants were collected and the concentration of mercury. The average temperature at which particular herbs were collected was established at $13.8 \pm 1.72{ }^{\circ} \mathrm{C}$ in the spring and $21.37 \pm 1.79{ }^{\circ} \mathrm{C}$ in the autumn. A significant correlation has been between the concentration of mercury in whole plants, leaves, inflorescences, and the temperature at which they were collected for leaves $(r=0.61 ; p<0.01)$, inflorescences $(r=0.87 ; p<0.05)$, and whole plants $(r=0.42 ; p<0.01)$.
Fig. 3 Correlation between concentration of mercury in autumn and spring in medicinal herbs

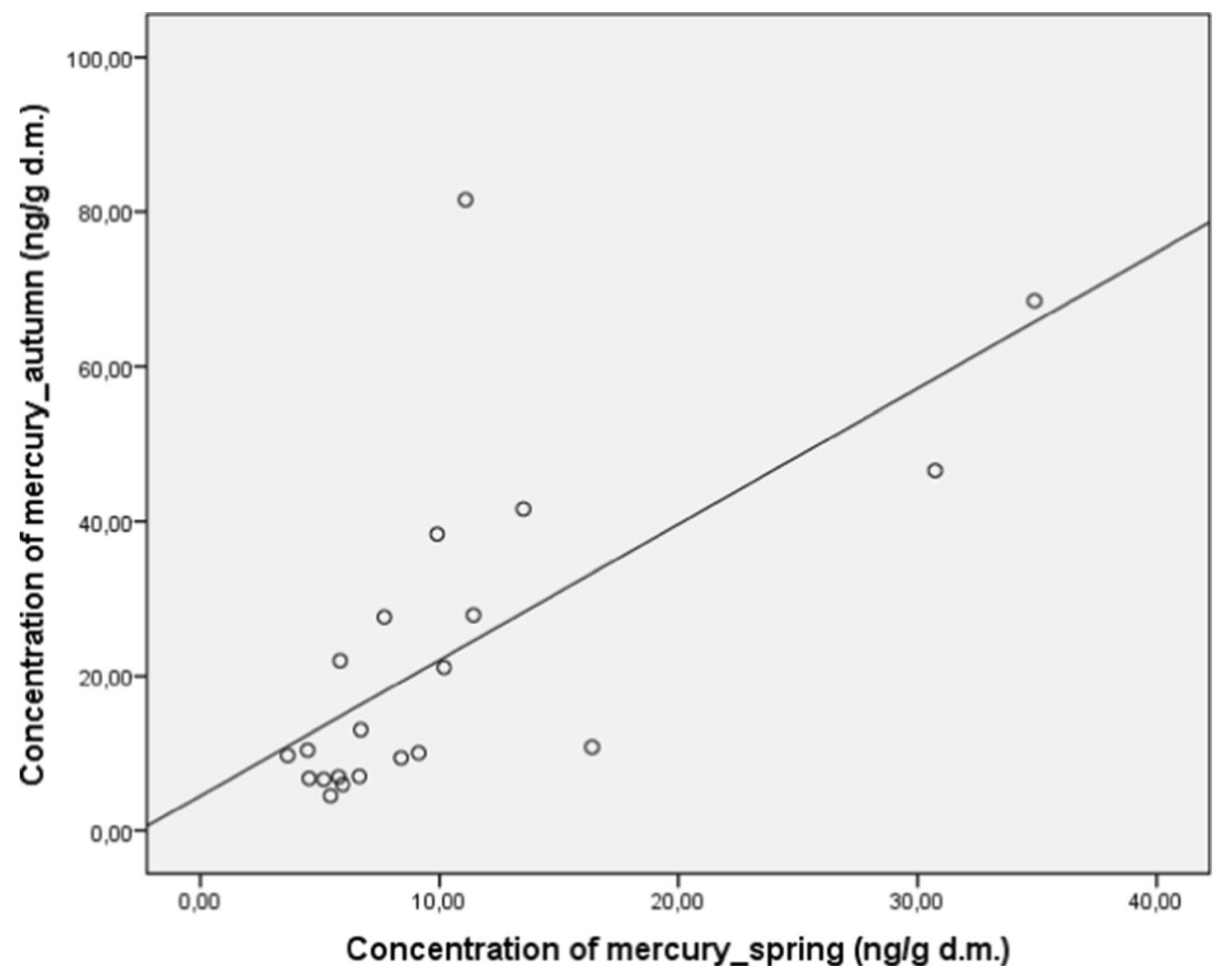


Fig. 4 Correlation between concentration of mercury in autumn and spring in polycarpic plants

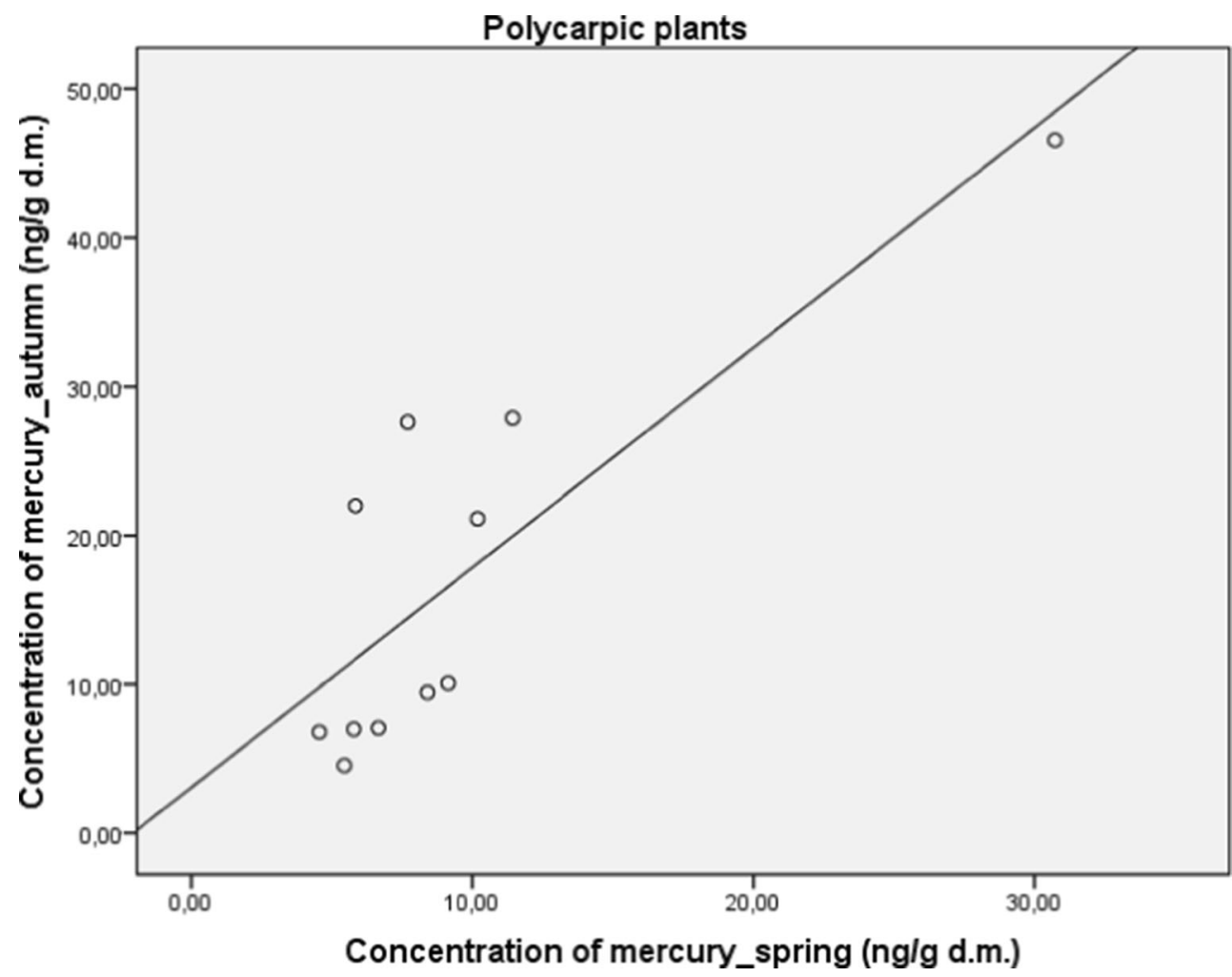

a certain limit, it is toxic and hazardous to plants, animals, and humans. Sparse literature data reveal that mercury can accumulate in human tissues due to the use of plant materials for therapeutic purposes. Herbal
Fig. 5 Correlation between concentration of mercury in autumn and spring in monocarpic plants
Except for cadmium and lead, mercury is included to heavy metals unnecessary for living organisms. Beyond

\section{Monocarpic plants}

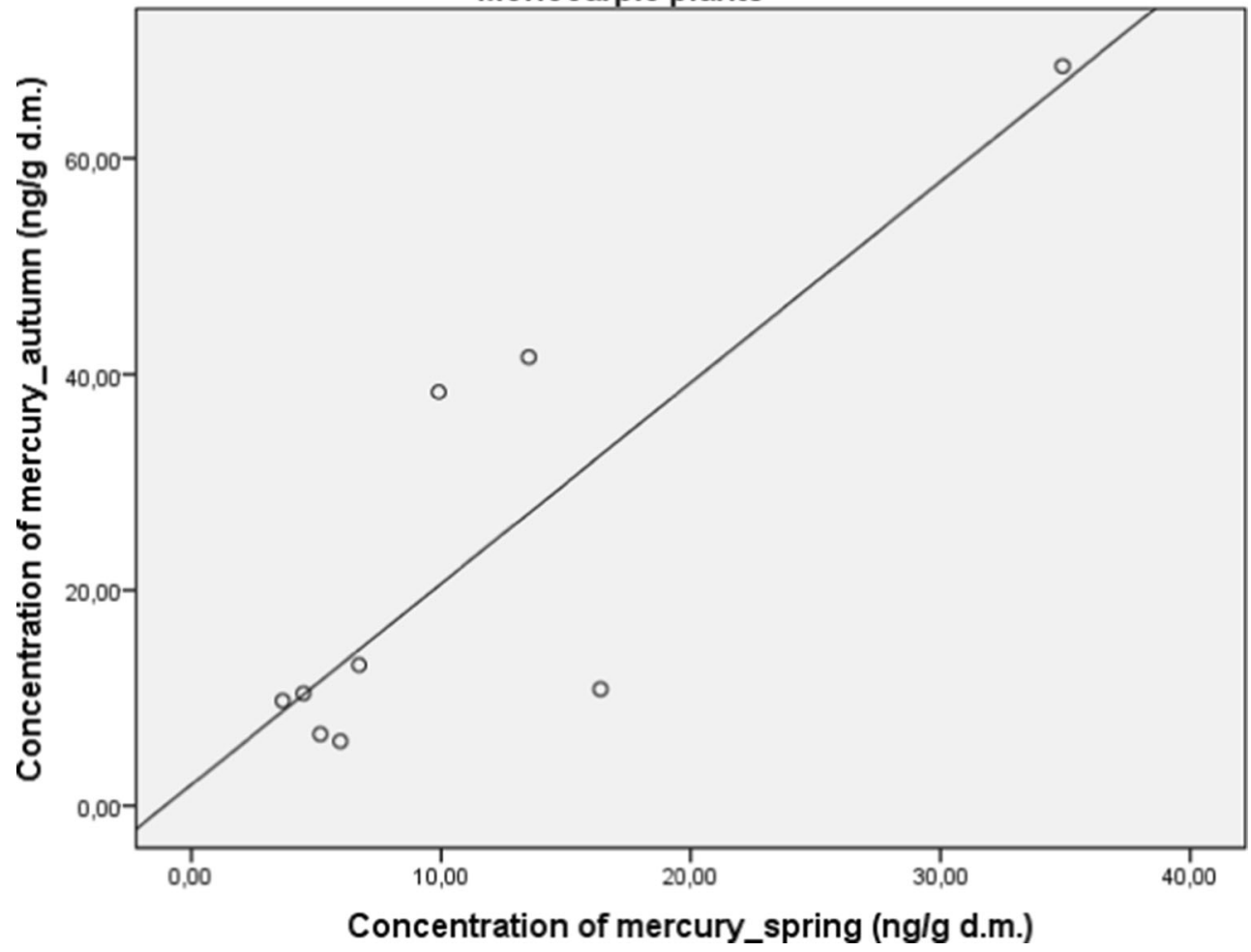


Fig. 6 Correlation between concentration of mercury in autumn and spring in more common plants

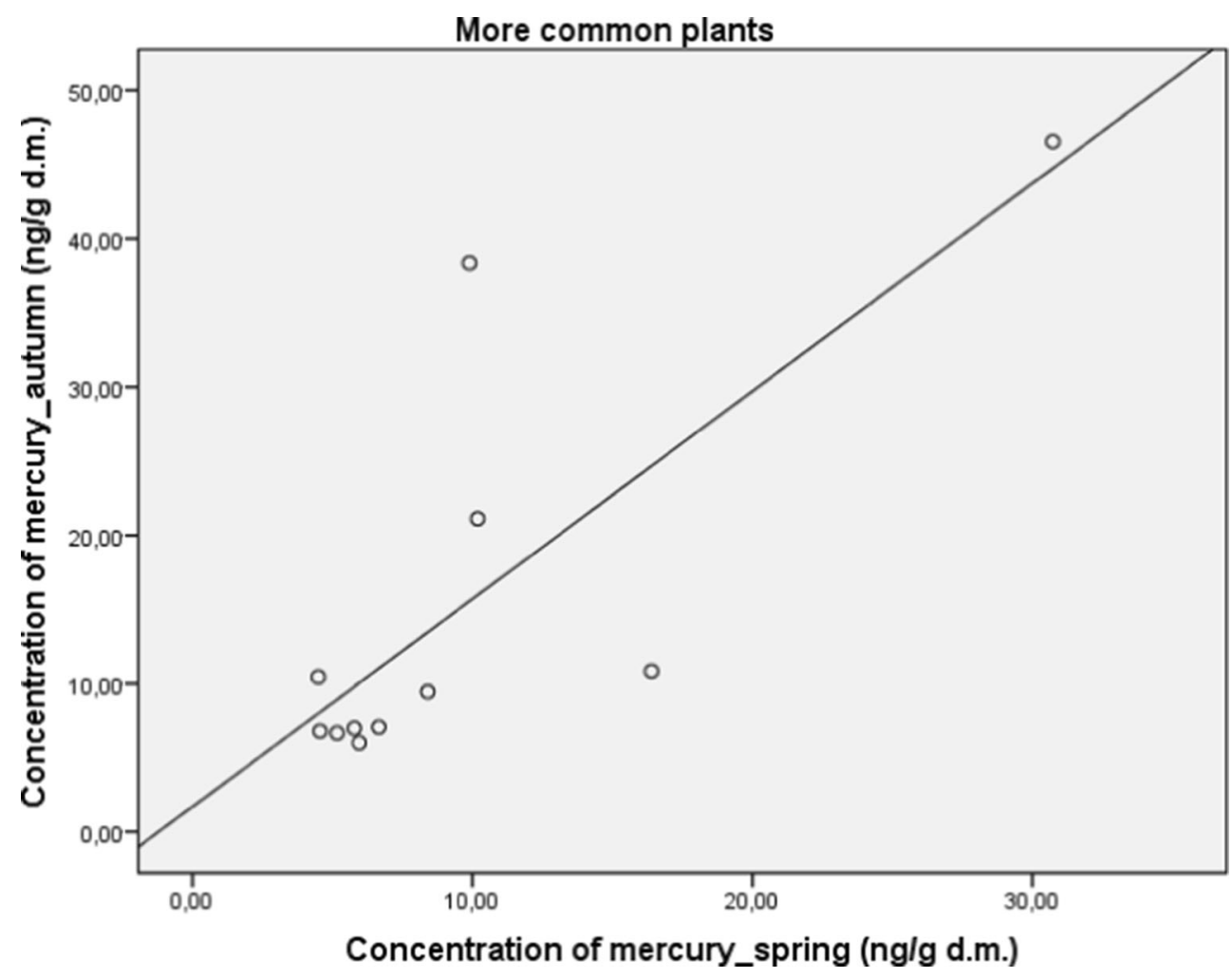

preparations with an increased content of toxic elements may become an additional source of their intake by human organism, and along with their beneficial effect, they can intoxicate the organism. The results of this study seem to indicate that the content of this toxic element in herbs depends on the following:
Fig. 7 Correlation between concentration of mercury in autumn and spring in less common plants

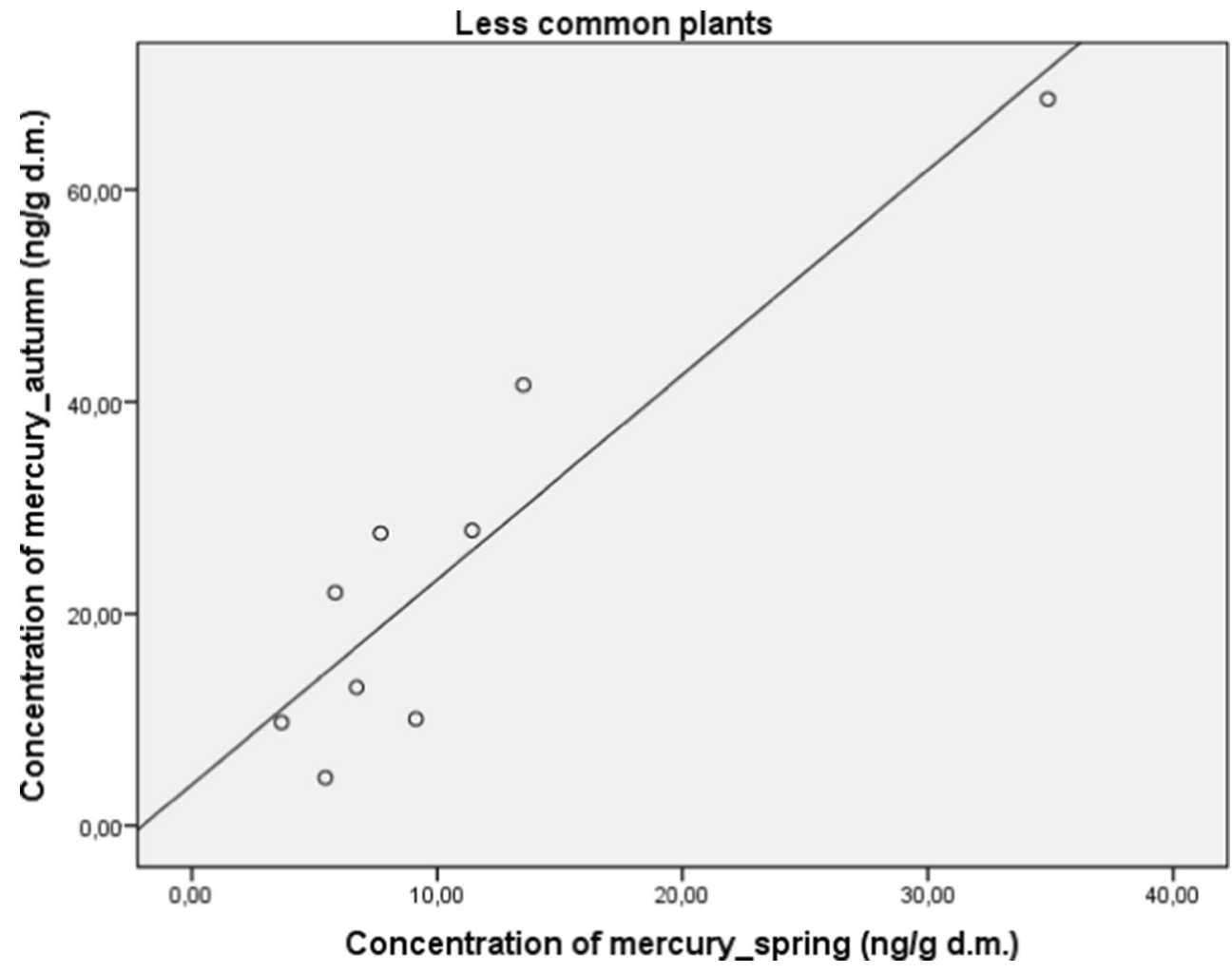




\section{a) Plant species}

Among 20 species of medicinal plants analyzed in this study for the mercury presence, it was found that the greatest predisposition for accumulation of this element was demonstrated by yew and the lowest by white dead-nettle. This probably results from the fact that the yew, as a perennial plant, deposits mercury accumulated by the roots in the leaves in subsequent vegetation seasons. The fact that the yew does not shed the needles for winter causes an increase in the mercury level in these organs [29]. In turn, white dead-nettle is an annual plant, and therefore, the time for mercury accumulation by this plant is shorter than the long time of the yew. Similarly, other annual plants such as dill and stinging nettle demonstrated small amounts of this element in the examined organs. Some plants characterized by high levels of mercury in their tissues produced deformed roots (daisy) and the leaves with chlorotic and brown spots (yew). Similar toxic effects of mercury on plants were described by other authors $[18,19]$.

\section{b) Degree of soil and atmosphere contamination}

In this study, the plants derived from relatively unpolluted sites, cultivated in soils where applicable, appropriate agricultural practices are applied, for example, in allotments, contained lower amounts of mercury compared to the species growing wild, harvested near busy streets. The amount of mercury uptaken from the soil by the root system of the plant depends on the degree of this element accumulation and capacity of its exclusion from the circulation through the soil sorption complex [30]. Soil properties such as high $\mathrm{pH}$, high content of floatable fraction (mostly colloidal clay), and humus are the factors inhibiting mercury accumulation by the plants. Then, mercury is bound by an appropriate buffer system of the soil and becomes not assimilable for plant roots.

Furthermore, ionic relations of such elements as nitrogen, iron, calcium, and phosphorus in soil determine either the reduction (antagonism) or promotion (synergism) of absorption of mercury by plants [31]. Plant roots absorb mercury along with other substances from the soil. If there are no such competing substances, mercury absorption is relatively greater. The forest is an example of the natural ecosystem, in which the ecological balance is preserved. Probably favorable soil conditions in forest inhibited the accumulation of mercury in these plants.

A significantly higher level of mercury in medicinal herbs collected in the autumn in allotments and home gardens located in the close vicinity of busy streets compared to the plants collected in the forest could be due to unfavorable conditions of soils where the plants were grown or due to localization of allotments and kitchen gardens near streets; therefore, these plants were exposed to exhaust gases. The above-mentioned factors promote the accumulation of mercury in plants. A similar phenomenon has been observed in Poland when evaluating the content of $\mathrm{Hg}$ in soils of the Silesian-Cracow region [32]. Most of this metal was found in the surface layers of city parks' soil.

\section{c) Season of the year of plants harvesting}

Statistical analysis of the results confirmed a significant relationship, both in the group of polycarpic and monocarpic plants, between the metal concentration and season of the year. The higher was mercury concentration in both groups of plants in the spring, the higher was it in autumn. This research seems to indicate that the plants uptake mercury during the whole vegetation season, starting in spring, summer, and ending in autumn. Therefore, higher concentration of that element in the organs of examined species is found in autumn. Concurrently observed a statistically significant correlation between mercury concentration in herbs harvested in spring and autumn proves the dangerous phenomenon of mercury accumulation in plants in the autumn period.

It is worth mentioning that during the collection of plans for the study, in the spring and in the autumn, there was a relatively scant rainfall. Less rainfall was observed in the spring in comparison to the autumn. Along with rainfall, as a result of wet deposition, one can observe a drop of concentration of mercury on the soil surface and on the appropriate plant strata in the form of $\mathrm{Hg}^{2+}$ ion [12]. It is evidenced by the results presented in this paper, stating that in the autumn, there is a significantly higher level of mercury in the plants as compared to that in the spring.

The results of this study also showed that the higher the temperature at which the plants were collected, the higher the concentration of mercury in leaves, inflorescences, and whole plants. This is probably related to evaporation of elemental mercury from soils [33]. This process is more intense on warm days. Then, the reduction of mercury in the presence of organic matter and photolytic reactions with organic and other soil components reaches the highest intensity. During this process, the elemental $\mathrm{Hg}$ released to the atmosphere may be absorbed by both soil surface and plants.

\section{d) Kind of plant organ used in phytotherapy}

The analysis of mercury content in particular organs of 20 species of medicinal plants showed that the highest amounts of this element are accumulated in the leaves. This is probably related to the fact that the source of heavy metals for plants may be situated beyond the soil atmosphere. The amount of metal accumulated on the leaves mainly depends on the surface of the leaf blade which deposits dust from emission, weather conditions, amount of precipitation, as well as the direction and strength of the wind. This is confirmed by the literature data, which 
indicate diversified ability of plants to accumulate mercury, even within the same species. This was confirmed by the analysis of mercury content in common dandelion, where the mean concentration of the element was $5 \mathrm{ng} / \mathrm{g}$ in stem, $14 \mathrm{ng} / \mathrm{g}$ in leaves, $10 \mathrm{ng} / \mathrm{g}$ in blossom, and $12 \mathrm{ng} / \mathrm{g}$ in roots [34]. Moreover, the analysis of mercury content in corn showed a greater accumulation of mercury in leaves $(49 \mathrm{ng} / \mathrm{g})$ than in seeds $(10 \mathrm{ng} / \mathrm{g})$ [35].

\section{e) Length of vegetation period of specified plant species}

Significant differences in the examined plants were observed in the range of mercury concentration. Perennial herbs (polycarpic ones) exhibit significantly higher mercury levels compared to monocarpic herbs (annual or biennial). This is confirmed by the results of other authors, which show that the level of this element accumulation in plants increases over the time $[5,18]$. Similar results were obtained by examining mercury deposition in the atmosphere over China, as well as by analyzing the content of that element in the leaves of trees in southern Sweden [10, 12, 15, 17, 18].

\section{f) Utility of medicinal plants}

Due to their therapeutic effects, some plant species are more frequently used by people in phytotherapy and other ones less frequently. Significantly lower mercury concentrations were found in the raw plant material of these species compared to the plants more rarely used in phytotherapy. This may result from the fact that these species are the most commonly cultivated in gardens, on the soils where various agricultural practices are used to improve soils physical and chemical properties. Such activities restrict heavy metals uptake by the plants $[5,6,15,16]$. At the same time, it can be assumed that $\mathrm{Hg}$ content in the examined herbs derived from Polish pharmacies is safe and does not pose a risk to health. It should be concluded that plant raw materials which are often derived from natural sites are exposed to environmental pollutants. It is therefore necessary not only to analyze the content of active substances in the herbs that determine their therapeutic effects but also toxic and potentially toxic elements, e.g., mercury.

\section{Conclusions}

Comparing concentration of mercury in the studied medicinal herbs depending on the season of collection to the results in the literature, it was concluded that the results did not differ. This study indicates that concentration of mercury in the medicinal herbs depends on season of the year and place where they grow. The highest concentration of this element is accumulated in autumn and near busy roads. Taking into consideration morphological parts of the plants, highest concentration of mercury was found in leaves. Significant correlation between concentration of mercury in the medicinal herbs collected in autumn and spring suggests dangerous phenomenon of accumulation of this element. A stronger tendency to accumulation of mercury is shown by polycarpic and more commonly used plants in comparison to monocarpic and less common ones.

\section{Compliance with Ethical Standards}

Conflict of Interest The authors declare that they have no competing interests.

Open Access This article is distributed under the terms of the Creative Commons Attribution 4.0 International License (http:// creativecommons.org/licenses/by/4.0/), which permits unrestricted use, distribution, and reproduction in any medium, provided you give appropriate credit to the original author(s) and the source, provide a link to the Creative Commons license, and indicate if changes were made.

\section{References}

1. Suchacz B, Wesolowski M (2012) The analysis of heavy metals content in herbal infusions. Cent Eur J Med 7:457-464

2. Prakash MMSK, Naidu PVS, Muralidhar P (2006) Biologically estimation of heavy/toxic metals present in traditional medicinal plant-Eclipta alba. Int J Pharm Biomed Res 2:99-102

3. Caldas ED, Machado LL (2004) Cadmium, mercury and lead in medicinal herbs in Brazil. Food Chem Toxicol 42:599-603

4. Ericksen JA, Gustin MS, Schorran DE, Johnson DW, Lindberg SE, Coleman JS (2003) Accumulation of atmospheric mercury in forest foliage. Atm Environ 37:1613-1622

5. Lodenius M, Tulisalo E, Soltanpour-Gargari A (2003) Exchange of mercury between atmosphere and vegetation under contaminated conditions. Sci Total Environ 304:169-174

6. Cavallini A, Natali L, Durante M, Maserti B (1999) Mercury uptake, distribution and DNA affinity in durum wheat (Triticum durum Desf.) plants. Sci Total Environ 243-244:119-127

7. Jena V, Gupta S (2012) Study of heavy metal distribution in medicinal plant basil. J Environ Anal Toxicol 2:161

8. Carrasco-Gil S, Siebner H, Leduc DL, Webb SM, Millán R, Andrews RC, Hernández RE (2013) Mercury localization and speciation in plants grown hydroponically or in a natural environment. Environ Sci Technol 47:3082-3090

9. Lopes MS, Iglesia-Turiño S, Cabrera-Bosquet L, Serret MD, Bort J, Febrero A, Araus JL (2013) Molecular and physiological mechanisms associated with root exposure to mercury in barley. Metallomics 5:1305-1315

10. Guédron S, Grangeon S, Jouravel G, Charlet L, Sarret G (2013) Atmospheric mercury incorporation in soils of an area impacted by a chlor-alkali plant (Grenoble, France): contribution of canopy uptake. Sci Total Environ 445-446:356-364

11. Gworek B, Rateńska J (2009) Mercury migration in pattern air-soilplant. Environ Nat Res 41:614-623

12. Silva-Filho EV, Machado W, Oliveira RR, Sella SM, Lacerda LD (2006) Mercury deposition through litterfall in an Atlantic Forest at Ilha Grande, southeast Brazil. Chemosphere 65:2477-2484 
13. Rea AW, Lindberg SE, Keeler GJ (2001) Dry deposition and foliar leaching of mercury and selected trace elements in deciduous forest through fall. Atm Environ 35:3453-3462

14. Sas-Nowosielska A, Galimska-Stypa R, Kucharski R, Zielonka U, Małkowski E, Gray L (2008) Remediation aspect of microbial changes of plant rhizosphere in mercury contaminated soil. Environ Monit Assess 137:101-109

15. Hissler CH, Probst JL (2006) Impact of mercury atmospheric deposition on soils and streams in a mountainous catchment (Vosges, France) polluted by chlor-alkali industrial activity: the important trapping role of the organic matter. Sci Total Environ 361:163-178

16. Xu J, Bravo AG, Lagerkvist A, Bertilsson S, Sjöblom R, Kumpiene $\mathrm{J}$ (2015) Sources and remediation techniques for mercury contaminated soil. Environ Int 74:42-53

17. Tan H, He JL, Liang L, Lazoff S, Sommer J, Xiao ZF, Lindqvist O (2000) Atmospheric mercury deposition in Guizhou, China. Sci Total Environ 259:223-230

18. Yu X, Driscoll CT, Huang J, Holsen TM, Blackwell BD (2013) Modeling and mapping of atmospheric mercury deposition in Adirondack Park, New York. PLoS one 8(3):e59322

19. Greger M, Wang Y, Neuschütz C (2005) Absence of transpiration by shoot after $\mathrm{Hg}$ uptake by roots of six terrestrial plant species. Environ Pollut 134:201-208

20. Skinner K, Wright N, Porter-Goff E (2007) Mercury uptake and accumulation by four species of aquatic plants. Environ Pollut 145:234-237

21. Ericksen JA, Gustin MS (2004) Foliar exchange of mercury as a function of soil and air mercury concentrations. Sci Total Environ 324:271-279

22. Laacouri A, Nater EA, Kolka RK (2013) Distribution and uptake dynamics of mercury in leaves of common deciduous tree species in Minnesota. Environ Sci Technol 47:10462-10470

23. Zahir F, Rizwi SJ, Haq SK, Khan RH (2005) Low dose mercury toxicity and human health. Environ Toxicol Pharmacol 20:351-360

24. Rafati-Rahimzadeh M, Rafati-Rahimzadeh M, Kazemi S, Moghadamnia AA (2014) Current approaches of the management of mercury poisoning: need of the hour. DARU J Pharm Sci 22:46
25. Han FX, Patterson WD, Xia Y, Sridhar BBM, Su Y (2006) Rapid determination of mercury in plant and soil samples using inductively coupled plasma atomic emission spectroscopy, a comparative study. Water Air Soil Pollut 170:161-171

26. Bansal N, Vaughan J, Boullemant A, Leong T (2013) The determination of trace mercury in environmental samples: a review. Chemeca 41:771-776

27. Ulewicz-Magulska B, Wesolowski M (2013) A chemometric approach to distribution of selenium in medicinal plants cultivated in Poland. J Med Food 16:460-466

28. Regulation (2003) Regulation of the Minister of Health of January 13, 2003 on maximum levels of chemical and biological contaminants that may be present in food, food ingredients, allowed additional substances, substances or processing aids on food. Dz.U. 37, 326

29. Obrist D, Johnson DW, Edmonds RL (2012) Effects of vegetation type on mercury concentrations and pools in two adjacent coniferous and deciduous forests. J Plant Nutr Soil Sci 175:68-77

30. Wuana RA, Okieimen FE (2011) Heavy metals in contaminated soils: a review of sources, chemistry, risks and best available strategies for remediation. ISRN Ecology, 4, 20. Article ID 402647

31. Kabata-Pendias A, Pendias H (2001) Trace elements in soils and plants, 3rd edn. CRC Press, Boca Raton

32. Pasieczna A (2014) Mercury in soils, and river and stream sediments in the Silesia-Cracow region (southern Poland). Bull Geol Inst 457:69-86

33. Chibuike GU, Obiora SC (2014) Heavy metal polluted soils: effect on plants and bioremediation methods. Appl Environ Soil Sci 12: article ID 752708

34. Kwapulinski J, Kowol J, Ciba J, Sarosiek H, Wrobel R, Rochel M, Bogunia M (2000) Mercury content of dandelion exposed to reemitted road traffic dusts. Bromat Chem Toksykol 33:183-188

35. Guangle Q, Xinbin F, Shaofeng W, Lihai S (2006) Environmental contamination of mercury from $\mathrm{Hg}$-mining areas in Wuchuan, northeastern Guizhou, China. Environ Pollut 142:549-558 